\title{
KEWENANGAN PEMBUATAN AKTA BAGI NOTARIS YANG BERADA DI DAERAH PROVINSI HASIL PEMEKARAN
}

\author{
Hasanuddin Kusuma Negara \\ Universitas Narotama Surabaya / hasan.kusumonegoro@gmail.com \\ Moh. Saleh \\ Universitas Narotama Surabaya (Dosen)
}

\begin{abstract}
Today the territory of the Unitary Republic of Indonesia is growing rapidly with the emergence of new regions resulting from regional formation. Both the results of regional merger and regional expansion. At present the territory of the Unitary Republic of Indonesia consists of 34 provinces, 416 districts, 98 cities, 7,094 sub-districts, 8,412 villages, and 74,093 villages. This has an impact on the Notary's domicile and Notary's office. So that problems arise. How is the authority of the Notary in the new area resulting from the division. Because the Notary must automatically adjust to the new regional administration because of the change in the place of domicile and the position of the Notary. Then what is the limitation of authority from making a deed by a notary who has not adjusted to the new area of the division. In this case the Notary has not received a Position Adjustment Decree by the Minister. This research is a type of normative legal research and the approach used is the statute approach and conceptual approach. The results of this paper conclude that the limitation of the authority to make a deed for Notaries located in the provincial region as a result of the division is limited by three things: content / material (material), space (locus), and time (tempus). Then the legal consequence if the Notary violates the authority limit is the notary action is an unauthorized action (onbevoegheid), namely: onbevoegdheid ratione materiae, onbevoegdheid ratione loci, and onbevoegdheid ratione temporis. And actions without authority result in the deed being null and void.
\end{abstract}

Keywords: Authority, Notary, Deed, Expansion

Hasanuddin Kusuma Negara dan Moh. Saleh, Kewenangan Pembuatan Akta bagi Notaris yang berada di Daerah Provinsi Hasil Pemekaran

JURNAL TRANSPARANSI HUKUM. VOL 1. NO.2. 


\begin{abstract}
Abstrak : Dewasa ini wilayah Negara Kesatuan Republik Indonesia berkembang pesat dengan munculnya daerah-daerah baru hasil dari pembentukan daerah. Baik dari hasil penggabungan daerah maupun pemekaran daerah. Saat ini wilayah Negara Kesatuan Republik Indonesia terdiri dari 34 provinsi, 416 kabupaten, 98 kota, 7.094 kecamatan, 8.412 kelurahan, dan 74.093 desa. Hal ini berdampak pada tempat kedudukan Notaris dan wilayah jabatan Notaris. Sehingga timbul permasalahan. Bagaimana kewenangan Notaris di daerah baru hasil pemekaran. Karena secara otomatis Notaris harus menyesuaikan dengan administrasi daerah baru tersebut karena terjadinya perubahan tempat kedudukan dan wilayah jabatan Notaris. Lalu bagaimana batasan kewenangan dari pembuatan akta oleh notaris yang belum menyesuaikan dengan daerah baru hasil pemekaran tersebut. Dalam hal ini Notaris belum mendapatkan Keputusan Penyesuaian Tempat Kedudukan oleh Menteri. Penelitian ini bertipe penelitian hukum normatif dan pendekatan yang dipergunakan adalah pendekatan perundang-undangan (statute approach) dan pendekatan konseptual (conceptual approach). Hasil tulisan ini menyimpulkan bahwa Batasan kewenangan pembuatan akta bagi Notaris yang berada di daerah provinsi hasil pemekaran yaitu dibatasi oleh tiga hal : isi/materi (materiae), ruang/tempat (locus), dan waktu (tempus). Lalu akibat hukum jika Notaris melanggar batasan kewenangan tersebut yaitu tindakan notaris adalah tindakan tanpa wewenang (onbevoegheid), yaitu : onbevoegdheid ratione materiae, onbevoegdheid ratione loci, dan onbevoegdheid ratione temporis. Dan tindakan tanpa wewenang mengakibatkan akta tersebut batal demi hukum.
\end{abstract}

Kata kunci : Kewenangan, Notaris, Akta, Pemekaran

Hasanuddin Kusuma Negara dan Moh. Saleh, Kewenangan Pembuatan Akta bagi Notaris yang berada di Daerah Provinsi Hasil Pemekaran 


\section{A. PENDAhULUAN}

Kedudukan seorang Notaris adalah menjadi seorang fungsionaris di dalam masyarakat dan menjadi pejabat yang dapat diandalkan oleh masyarakat umum. Daripada itu Jabatan Notaris pada umumnya juga dianggap sebagai salah satu pejabat tempat siapa saja dapat meminta nasihat hukum yang dapat diandalkan. Segala pernyataan yang ditulis serta ditetapkannya atau di konstatir adalah benar dan valid, dan Notaris merupakan pembuat dokumen yang terkuat dalam suatu pembuktian hukum.

Jabatan Notaris di Indonesia tertuang di dalam Undang-undang Jabatan Notaris (UUJN) sebagai salah satu produk hukum di Indonesia. UUJN ini merupakan hakikat penerapan dari Pasal 1868 Kitab Undang-undang Hukum Perdata (KUHPerdata) yang menyatakan bahwa, "suatu akta otentik adalah suatu akta yang dibuat dalam bentuk yang ditentukan undang-undang oleh atau dihadapan pejabat umum yang berwenang untuk itu di tempat akta itu dibuat." 1 Pasal 1868 KUHPerdata ini telah menunjuk seorang Pejabat Umum yang mempunyai kewenangan membuat akta otentik yaitu Pejabat Notaris.

Pasal 1 angka 1 UUJN menyebutkan bahwa, "Notaris adalah pejabat umum yang berwenang untuk membuat akta otentik dan kewenangan lainnya sebagaimana dimaksud dalam undang-undang ini." 2 UUJN merupakan penyempurnaan dari undang-undang peninggalan jaman kolonial dan unifikasi sebagian besar undang-undang yang mengatur mengenai kenotariatan yang sudah tidak sesuai dengan perkembangan hukum dan kebutuhan masyarakat sekarang. ${ }^{3}$

Selanjutnya dijelaskan pada Penjelasan Undang-Undang Republik Indonesia Nomor 2 Tahun 2014 Tentang Perubahan Atas Undang-Undang Nomor 30 Tahun 2004 Tentang Jabatan Notaris. Pada Alinea kesatu dijelaskan bahwa "Negara Republik Indonesia sebagai negara hukum berdasarkan Pancasila dan UndangUndang Dasar Negara Republik Indonesia Tahun 1945 menjamin kepastian,

\footnotetext{
${ }^{1}$ Pasal 1868 Kitab Undang-undang Hukum Perdata (selanjutnya disebut KUHPerdata)

${ }^{2}$ Pasal 1 angka 1 Undang-undang Jabatan Notaris (selanjutnya disebut UUJN).

${ }^{3}$ Reglement Op Het Notaris ambt in Indonesia (Stb. 1860:3) sebagaimana telah diubah terakhir dalam Lembaran Negara Th. 1945 No. 101.
}

Hasanuddin Kusuma Negara dan Moh. Saleh, Kewenangan Pembuatan Akta bagi Notaris yang berada di Daerah Provinsi Hasil Pemekaran 
ketertiban, dan perlindungan hukum bagi setiap warga negara. Untuk menjamin kepastian, ketertiban, dan perlindungan hukum dibutuhkan alat bukti tertulis yang bersifat autentik mengenai perbuatan, perjanjian, penetapan, dan peristiwa hukum yang dibuat di hadapan atau oleh Notaris." 4

Selanjutnya dijelaskan pada pasal 15 ayat 1 Undang-Undang Jabatan Notaris (UUJN) yang menyebutkan bahwa "Notaris berwenang membuat Akta autentik mengenai semua perbuatan, perjanjian, dan penetapan yang diharuskan oleh peraturan perundang-undangan dan/atau yang dikehendaki oleh yang berkepentingan untuk dinyatakan dalam Akta autentik, menjamin kepastian tanggal pembuatan Akta, menyimpan Akta, memberikan grosse, salinan dan kutipan Akta, semuanya itu sepanjang pembuatan Akta itu tidak juga ditugaskan atau dikecualikan kepada pejabat lain atau orang lain yang ditetapkan oleh undang-undang". 5

Kemudian mengenai Akta, Akta Otentik adalah akta yang dibuat oleh seorang pejabat yang diberi wewenang atau tugas untuk itu oleh penguasa, menurut ketentuan-ketentuan undang-undang yang telah ditetapkan, baik dengan para pihak maupun tanpa bantuan dari pihak yang berkepentingan, yang mencatat apa yang dimintakan untuk dimuat di dalamnya oleh pihak yang berkepentingan, akta otentik dibuat terutama di dalam isinya memuat keterangan seorang pejabat (relaas), yang menerangkan apa yang dilakukannya dan yang telah dilihat di hadapannya tempat kedudukan Notaris berada. Dalam Pasal 165 HIR dan Pasal $285 \mathrm{Rbg}$, "akta otentik adalah suatu akta yang dibuat oleh atau dihadapan pejabat yang diberi wewenang untuk itu, merupakan bukti yang lengkap antara para pihak dan para ahli warisnya dan mereka yang mendapat hak daripadanya tentang yang tercantum di dalamnya dan bahkan sebagai pemberitahuan belaka, akan tetapi yang terakhir ini hanya diberitahukan itu berhubungan dengan perihal pada akta

4 Alinea ke-1 Penjelasan Undang-Undang Republik Indonesia Nomor 2 Tahun 2014 Tentang Perubahan Atas Undang-Undang Nomor 30 Tahun 2004 Tentang Jabatan Notaris.

${ }^{5}$ Pasal 15 ayat 1 UUJN.

Hasanuddin Kusuma Negara dan Moh. Saleh, Kewenangan Pembuatan Akta bagi Notaris yang berada di Daerah Provinsi Hasil Pemekaran 
itu." ${ }^{6}$ Pejabat yang dimaksudkan dalam hal ini antara lain ialah Notaris, Pegawai Pencatat Sipil, Panitera, Hakim, Jurusita, dan sebagainya.

Akta otentik sesuai ketentuan pada Pasal 1868 Kitab Undang-Undang Hukum Perdata (KUHPerdata) disebutkan bahwa "Suatu akta otentik ialah suatu akta yang di dalam bentuk yang ditentukan oleh undang-undang, dibuat oleh atau dihadapan pegawai-pegawai umum yang berkuasa untuk itu di tempat di mana akta dibuatnya." Selanjutnya dijelaskan oleh R. Soergondo, bahwa "akta otentik adalah akta yang dibuat dan diresmikan dalam bentuk hukum, oleh atau dihadapan pejabat umum, yang berwenang untuk berbuat sedemikian itu, ditempat dimana akta itu dibuat." 8

Pada isi pasal 18 ayat 1 UUJN menyebutkan bahwa "Notaris mempunyai tempat kedudukan di daerah kabupaten atau kota". ${ }^{9}$ Kemudian pada pasal 18 ayat 2 UUJN disebutkan "Notaris mempunyai wilayah jabatan meliputi seluruh wilayah provinsi dari tempat kedudukannya". ${ }^{10}$ Dapat ditarik kesimpulan jika tempat kedudukan Notaris harus atau wajib berada di dalam atau di wilayah atau di provinsi yang sama dengan wilayah jabatannya. Sebagai contoh apabila seorang Notaris tempat kedudukannya berada di Kota Surabaya, maka Notaris tersebut wilayah jabatannya di provinsi dimana tempat kedudukannya berada, yaitu provinsi Jawa Timur. Begitu pula sebaliknya, jika Notaris wilayah jabatannya adalah provinsi Jawa timur, maka tempat kedudukan Notaris tersebut harus berada di kota atau kabupaten di dalam wilayah provinsi tersebut, seperti kota Surabaya, kota Kediri, kota Malang, kota Batu, kabupaten Bojonegoro, dan lain-lain.

Membahas tempat kedudukan dan wilayah jabatan Notaris, hal ini berkaitan juga dengan perkembangan wilayah yang terjadi di Indonesia. Dewasa ini, sesuai dengan perkembangan yang terjadi di wilayah Negara Kesatuan Negara Republik Indonesia. Kita ketahui bahwa di daerah-daerah telah terjadi pembentukan daerah baru dari tahun ke tahun. Baik itu pembentukan daerah dengan cara

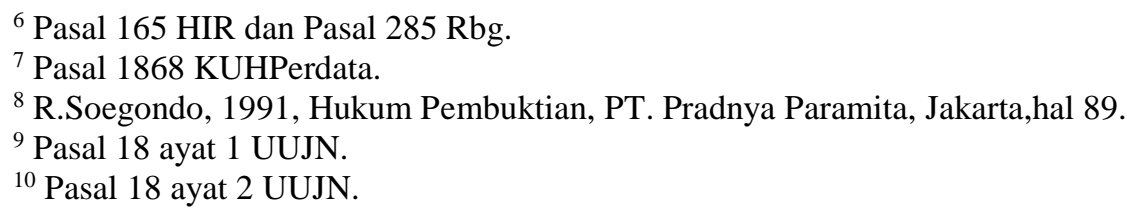

Hasanuddin Kusuma Negara dan Moh. Saleh, Kewenangan Pembuatan Akta bagi Notaris yang berada di Daerah Provinsi Hasil Pemekaran 
penggabungan daerah maupun pemekaran daerah. Baik terjadi dalam skala kota atau kabupaten maupun skala yang lebih luas lagi yaitu provinsi. Merujuk pada perkembangan di wilayah Negara Kesatuan Republik Indonesia, sampai saat ini wilayah Indonesia terdiri dari 34 provinsi, 416 kabupaten, 98 kota, 7.094 kecamatan, 8.412 kelurahan, dan 74.093 desa. $^{11}$

Berdasarkan atas dasar penjelasan perundang-undangan dan fakta-fakta yang telah dipaparkan di atas, penulis menarik kesimpulan bahwa antara tempat kedudukan dan wilayah jabatan Notaris beserta kewenangan yang dimiliki Notaris sangat berkaitan erat, dan merupakan bagian yang tidak terpisahkan dengan perkembangan pembentukan daerah. Selanjutnya timbul permasalahan, bagaimana jika seorang Notaris yang telah mempunyai kewenangan di wilayah jabatannya berdasarkan surat keputusan Kemenkumham berdasarkan pengangkatan atau perpindahan Notaris, dan wilayah jabatan Notaris tersebut mengalami pemekaran daerah. Dalam hal ini tentu terbentuknya suatu administrasi pemerintahan yang baru di wilayah daerah pemekaran tersebut.

Pada isi yang tertuang dalam Peraturan Menteri Hukum dan Hak Asasi Manusia (Permenkumham) Republik Indonesia Nomor 25 Tahun 2014 tentang syarat dan tata cara pengangkatan, perpindahan, pemberhentian, dan perpanjangan masa Jabatan Notaris. Pada pasal 37 ayat 1 disebutkan "Dalam hal terjadi pemekaran kabupaten/kota, yang mengakibatkan terjadinya perubahan tempat kedudukan Notaris maka tempat kedudukan yang tercantum dalam keputusan pengangkatan Notaris atau keputusan perpindahan Notaris yang bersangkutan dapat diubah sesuai dengan permohonan". ${ }^{12}$ Selanjutnya pada Permenkumham No. 25 Tahun 2014 pasal 37 ayat 2 disebutkan "Notaris yang bersangkutan wajib memberitahukan secara elektronik kepada Menteri mengenai perubahan tempat kedudukan Notaris karena alasan sebagaimana dimaksud pada ayat (1) dalam jangka waktu paling lama 90 (Sembilan puluh) hari terhitung sejak tanggal

11 "Data Wilayah Administrasi Seluruh Indonesia", www.kemendagri.go.id diakses pada tanggal 1 Februari 2018.

12 Pasal 37 ayat 1 Peraturan Menteri Hukum dan Hak Asasi Manusia Republik Indonesia Nomor 25 Tahun 2014 tentang syarat dan tata cara pengangkatan, perpindahan, pemberhentian, dan perpanjangan masa Jabatan Notaris (selanjutnya disebut Permenkumham No. 25 Tahun 2014).

Hasanuddin Kusuma Negara dan Moh. Saleh, Kewenangan Pembuatan Akta bagi Notaris yang berada di Daerah Provinsi Hasil Pemekaran 
Undang-undang mengenai pemekaran wilayah diundangkan". ${ }^{13}$ Selanjutnya pada pasal 37 ayat 4 berbunyi "Terhadap pemberitahuan sebagaimana dimaksud pada ayat (3), Menteri mengeluarkan Keputusan Penyesuaian tempat kedudukan”. Penulis menyimpulkan bahwa apabila terjadi pemekaran daerah, maka Notaris wajib membuat permohonan kepada Menteri dengan rentang waktupaling lama 90 (Sembilan puluh) hari. Selanjutnya Menteri menindak lanjuti dengan mengeluarkan Keputusan Penyesuaian Tempat Kedudukan. Atas dasar pasal 37 Permenkumham No. 25 / 2014 tersebut, timbul pertanyaan apa saja batasan kewenangan pembuatan akta bagi Notaris di daerah pemekaran, dan apa akibat hukum dari pembuatan akta bagi Notaris di daerah pemekaran.

Selanjutnya untuk menghindari meluasnya pembahasan yang akan diteliti oleh penulis, maka penulis membatasi ruang lingkup permasalahan yang akan dibahas, yaitu mengenai tindakan Notaris dalam membuat akta yang berada di daerah provinsi hasil pemekaran. Sehingga untuk pemekaran daerah dipersempit pembahasannya hanya untuk pemekaran provinsi. Dalam hal ini penulis berpendapat bahwa wilayah jabatan Notaris itu meliputi satu wilayah provinsi, sehingga tidak perlu pembahasan untuk pemekaran kota/kabupaten.

\section{B. PERMASALAHAN}

Berdasarkan uraian di atas, maka diperoleh permasalahan yaitu :

1) Apa saja batasan kewenangan pembuatan akta bagi Notaris yang berada di daerah provinsi hasil pemekaran ?

2) Apa akibat hukum pembuatan akta bagi Notaris yang berada di daerah provinsi hasil pemekaran?

\section{TINJAUAN PUSTAKA}

\section{Jabatan Notaris}

"Kedudukan seorang notaris sebagai seorang fungsionaris dalam masyarakat sebagai seorang pejabat yang dapat diandalkan oleh masyarakat.

${ }^{13}$ Pasal 37 ayat 2 Permenkumham No. 25 Tahun 2014.

Hasanuddin Kusuma Negara dan Moh. Saleh, Kewenangan Pembuatan Akta bagi Notaris yang berada di Daerah Provinsi Hasil Pemekaran 
Seorang notaris biasanya dianggap sebagai seorang pejabat tempat seseorang dapat memperoleh nasihat yang dapat diandalkan. Segala sesuatu yang ditulis serta ditetapkannya (konstatir) adalah benar, notaris merupakan pembuat dokumen yang kuat dalam suatu proses hukum." 14

Jabatan Notaris di Indonesia tertuang di dalam Undang-undang Jabatan Notaris (UUJN) sebagai salah satu produk hukum di Indonesia. UUJN ini merupakan hakikat penerapan dari Pasal 1868 Kitab Undangundang Hukum Perdata (KUHPerdata) yang menyatakan bahwa, "suatu akta otentik adalah suatu akta yang dibuat dalam bentuk yang ditentukan undang-undang oleh atau dihadapan pejabat umum yang berwenang untuk itu di tempat akta itu dibuat." 15 Pasal 1868 KUHPerdata ini telah menunjuk seorang Pejabat Umum yang mempunyai kewenangan membuat akta otentik yaitu Pejabat Notaris.

Pasal 1 angka 1 UUJN menyebutkan bahwa, "Notaris adalah pejabat umum yang berwenang untuk membuat akta otentik dan kewenangan lainnya sebagaimana dimaksud dalam undang-undang ini." UUJN merupakan penyempurnaan dari undang-undang peninggalan jaman kolonial dan unifikasi sebagian besar undang-undang yang mengatur mengenai kenotariatan yang sudah tidak sesuai lagi dengan perkembangan hukum dan kebutuhan masyarakat. ${ }^{16}$

Profesi Notaris di Indonesia merupakan salah satu profesi yang cukup tua. Hal ini dapat dilihat dari sejarah hukum kenotariatan di Indonesia yang dimulai pada abad ke-17 dengan adanya "Oost Ind. Compagnie". ${ }^{17}$ Keberadaan Notaris sangat dibutuhkan oleh masyarakat, hal ini disebabkan masyarakat memerlukan seseorang yang keterangan-keterangannya dapat dihandalkan, dapat dipercayai, yang tanda tangannya beserta segelnya

\footnotetext{
14 Than Thong Kie, Studi Notariat, Serba Serbi Praktek Notaris, Jakarta: PT Ichtiar Baru Van Hoeve, 2007.

${ }^{15}$ Pasal 1868 KUHPerdata.

${ }^{16}$ Reglement Op Het Notaris ambt in Indonesia (Stb. 1860:3) sebagaimana telah diubah terakhir dalam Lembaran Negara Th. 1945 No. 101.

${ }^{17}$ G.H.S. Lumban Tobing, Peraturan Jabatan Notaris, Jakarta: Erlangga.
}

Hasanuddin Kusuma Negara dan Moh. Saleh, Kewenangan Pembuatan Akta bagi Notaris yang berada di Daerah Provinsi Hasil Pemekaran 
(capnya) sedapat mungkin memberikan jaminan dan bukti yang kuat, seorang ahli yang kedudukannya tidak memihak dan penasihat yang tidak memiliki cacat, yang bisa tutup mulut, dan membuat suatu hal perjanjian yang dapat memberikan perlindungan di masa yang akan datang. Kalau seorang penasihat hukum atau advokat membela hak-hak dari seorang klien ketika timbul suatu permasalahan atau kesulitan, maka seorang Pejabat Notaris harus berusaha untuk mencegah terjadinya kesulitan klien di masa yang akan datang. ${ }^{18}$

Di dalam isi Peraturan Jabatan Notaris (PJN) Tahun 1860 (Reglement op het Notarisambt in Indonesie) disebutkan dan ditegaskan bahwa pekerjaan Pejabat Notaris merupakan suatu pekerjaan resmi (ambtelijke verrichtingen) dan merupakan satu-satunya pejabat umum yang berwenang untuk membuat akta otentik, sepanjang tidak ada peraturan lain yang memberi wewenang serupa kepada pejabat lain. ${ }^{19}$

PJN Tahun 1860 di dalamnya telah menyebutkan dengan sangat jelas bahwa notaris merupakan satu-satunya pejabat umum yang berwenang membuat akta otentik, kecuali jika ada pejabat lain yang ditentukan oleh undang-undang.

\section{Akta Otentik}

Pengertian Akta Otentik yaitu akta yang dibuat oleh seorang pejabat yang telah diberi wewenang untuk hal itu oleh penguasa, menurut ketentuan-ketentuan atau peraturan-peraturan yang telah ditetapkan, baik dalam pembuatannya dengan maupun tanpa bantuan dari pihak yang berkepentingan, yang bertugas mencatat apa saja yang dimintakan untuk dimuat di dalamnya oleh pihak yang berkepentingan, akta otentik utamanya memuat segala keterangan seorang pejabat umum, yang menerangkan tentang apa yang dilakukannya dan telah dilihat di hadapannya. Di dalam

\footnotetext{
18 Than Thong Kie, Studi Notariat, Serba Serbi Praktek Notaris, hal. 449.

${ }^{19}$ Anke Dwi Saputra, Jati Diri Notaris Indonesia Dulu, Sekarang, dan di Masa Yang Akan Datang, Jakarta: PT. Gramedia, 2008, hal. 229.
}

Hasanuddin Kusuma Negara dan Moh. Saleh, Kewenangan Pembuatan Akta bagi Notaris yang berada di Daerah Provinsi Hasil Pemekaran 
Pasal 165 HIR dan Pasal 285 Rbg, "akta otentik adalah suatu akta yang dibuat oleh atau dihadapan pejabat yang diberi wewenang untuk itu, merupakan bukti yang lengkap antara para pihak dan para ahli warisnya dan mereka yang mendapat hak daripadanya tentang yang tercantum di dalamnya dan bahkan sebagai pemberitahuan belaka, akan tetapi yang terakhir ini hanya diberitahukan itu berhubungan dengan perihal pada akta itu." 20 Pejabat yang dimaksudkan dalam pasal tersebut antara lain ialah Notaris, Pegawai Pencatat Sipil, Hakim, Panitera, Jurusita, dan sebagainya.

Akta otentik di dalam isi ketentuan Pasal 1868 Kitab Undang-Undang Hukum Perdata (KUHPerdata) disebutkan "Suatu akta otentik ialah suatu akta yang di dalam bentuk yang ditentukan oleh undang-undang, dibuat oleh atau dihadapan pegawai-pegawai umum yang berkuasa untuk itu di tempat di mana akta dibuatnya." 21 Dijelaskan juga oleh R. Soergondo, "akta otentik adalah akta yang dibuat dan diresmikan dalam bentuk hukum, oleh atau dihadapan pejabat umum, yang berwenang untuk berbuat sedemikian itu, ditempat dimana akta itu dibuat." 22

Irwan Soerodjo menjelaskan bahwa terdiri dari 3 (tiga) unsur esenselia supaya terpenuhinya syarat-syarat formal dari suatu akta otentik, yaitu: ${ }^{23}$

1) Di buat dalam bentuk yang telah ditentukan oleh undang-undang.

2) Dibuat oleh dan dilaksanakan di hadapan Pejabat Umum.

3) Akta yang telah dibuat oleh atau di hadapan seorang Pejabat Umum yang mempunyai atau berwenang untuk itu dan di tempat dimana akta itu dibuat.

Begitu pula sesuai dengan pernyataan C.A. Kraan akta otentik mempunyai beberapa ciri-ciri sebagai berikut, yaitu : ${ }^{24}$

${ }^{20}$ Pasal 165 HIR dan Pasal 285 Rbg.

${ }^{21}$ Pasal 1868 KUHPerdata.

${ }^{22}$ R.Soegondo, 1991, Hukum Pembuktian, PT. Pradnya Paramita, Jakarta,hal 89.

23 Irwan Soerodjo, 2003, Kepastian Hukum Hak Atas Tanah di Indonesia, Arkola, Surabaya, hal 148 .

${ }^{24}$ Herlien Budiono, 2007, Kumpulan Tulisan Hukum Perdata di Bidang Kenotariatan, Citra Aditya Bakti, Bandung, hlm.3-4.

Hasanuddin Kusuma Negara dan Moh. Saleh, Kewenangan Pembuatan Akta bagi Notaris yang berada di Daerah Provinsi Hasil Pemekaran 
1) Suatu bentuk tulisan, dengan telah sengaja dibuat dengan tujuan semata-mata untuk dijadikan alat bukti atau suatu bukti dari keadaan sebagaimana telah disebutkan di dalam tulisan yang dibuat dan dinyatakan atau ditetapkan oleh seorang pejabat yang berwenang. Tulisan yang dibuat tersebut turut ditandatangani oleh atau hanya ditandatangani oleh pejabat yang bersangkutan saja.

2) Suatu bentuk tulisan sampai ditemukan ada bukti sebaliknya, dianggap dibuat atau berasal dari pejabat yang berwenang untuk itu.

3) Ketentuan perundang-undangan yang harus atau wajib dipenuhi; ketentuan tersebut untuk mengatur tentang tata cara pembuatannya (setidak-tidaknya memuat tentang ketentuanketentuan mengenai tanggal akta, tempat dibuatnya akta suatu tulisan, nama dan kedudukan ataupun jabatan pejabat yang berwenang yang membuatnya).

4) Seorang pejabat yang telah diangkat oleh negara atau penguasa dan mempunyai sifat dan pekerjaan yang mandiri atau independen (onafhankelijk - independence) beserta tidak memihak (onpartijdigheid - impartiality) dalam menjalankan jabatannya itu.

5) Pernyataan menjelaskan dari fakta ataupun tindakan yang telah disebutkan oleh seorang pejabat adalah adanya hubungan hukum di dalam ranah atau bidang hukum privat. Akta Otentik yaitu suatu produk yang telah dibuat oleh seorang Pejabat notaris.

Dari penjelasan beberapa pendapat atau opini di atas yan telah dikemukakan, maka dapat diketahui dan ditarik kesimpulan bahwa bentukbentuk akta yang dapat dibuat oleh Pejabat notaris ada 2 (dua) macam yaitu:

1. Akta yang telah dibuat oleh (door) seorang Pejabat notaris atau yang dapat dinamakan akta relaas atau pada umumnya dinamakan akta pejabat (ambtelijke akte) merupakan akta yang telah dibuat oleh seorang pejabat yang telah diberi wewenang untuk itu, dimana

Hasanuddin Kusuma Negara dan Moh. Saleh, Kewenangan Pembuatan Akta bagi Notaris yang berada di Daerah Provinsi Hasil Pemekaran 
pejabat tersebut menerangkan apa saja yang dilihat serta apa saja yang telah dilakukannya, jadi inisiatif pembuatan akta tersebut tidak berasal dari orang/pihak yang namanya akan diterangkan di dalam akta tersebut. Ciri khas di dalam akta ini yaitu dengan tidak adanya atau tidak ditemukannya komparisi, dan Notaris mempunyai resiko jabatan dan bertanggung jawab penuh atas pembuatan akta tersebut.

2. Akta yang dibuat dihadapan (ten overstaan) seorang notaris atau yang pada umumnya dinamakan akta partij (partij-acteri) yaitu akta yang telah dibuat dihadapan seorang pejabat yang telah diberi wewenang untuk itu dan akta itu dibuat, dengan dasar atas permintaan dari para pihak-pihak yang mempunyai maksud atau yang berkepentingan. Adapun ciri khas pada akta ini yaitu adanya komparisi yang di dalamnya menjelaskan tentang kewenangan para pihak-pihak yang menghadap Notaris untuk membuat akta tersebut. ${ }^{25}$

Perbedaan-perbedaan akta yang telah dijelaskan diatas sangat penting dalam hal kaitannya dengan proses pembuktian sebaliknya (tegenbewijs) terhadap isi di dalam akta, sehingga dengan demikian terhadap segala kebenaran isi di dalam akta pejabat (ambtelijke akte) atau akta relaas yaitu tidak dapat digugat, terkecuali jika dengan menuduh bahwa akta itu adalah palsu, sedangkan pada suatu akta partij dapat digugat isinya yang tertuang di dalam akta, tanpa menuduh bahwa akta yang dibuat tersebut akta palsu akan tetapi hal ini dengan jalan menyatakan jika keterangan dari para pihakpihak yang membuat atau yang bersangkutan yang telah diuraikan dalam akta itu adalah tidak benar. Dalam hal pembuatan akta, baik akta relaas maupun akta partij yang menjadi landasan atau dasar utama atau inti dalam pembuatan suatu akta otentik, yaitu harus dengan adanya keinginan atau

25 Sjaifurrachman dan Habib Adjie, 2011, Aspek Pertanggungjawaban Notaris Dalam Pembuatan Akta, Mandar Maju, Bandung, hal 109.

Hasanuddin Kusuma Negara dan Moh. Saleh, Kewenangan Pembuatan Akta bagi Notaris yang berada di Daerah Provinsi Hasil Pemekaran 
kehendak (wilsvorming) dan permintaan oleh para pihak,, jika keinginan dan permintaan para pihak tidak ada, maka pejabat umum bersangkutan tidak akan membuat akta yang dimaksud. ${ }^{26}$

\section{Teori Kewenangan}

Wewenang (bevoegdheid/competencelermessen) tidak sama dengan kekuasaan (authority/macht). Kekuasaan merupakan konsep dalam Ilmu Politik, sedangkan wewenang merupakan konsep dalam Ilmu Hukum. Tentu keduanya memiliki perbedaan yang sangat prinsipil. Dalam konsep ilmu politik, kekuasaan dikonstruksikan sebagai fungsi politik yang dimiliki oleh organ negara dan oleh karenanya organ negara 'seolah' tanpa batas dapat melakukan tindakan apapun sepanjang fungsi politik yang diberikan kepadanya dapat terpenuhi/diwujudkan. Kekuasaan itu bersifat asli, bulat, dan tidak terbagi yang dimaksudkan untuk mempengaruhi orang lain sehingga mau tunduk pada kehendak yang diinginkannya.

Dalam Ilmu Hukum, khususnya Hukum Administrasi tidak mengenal istilah kekuasaan, melainkan wewenang. Dengan kata lain bahwa objek kajian Hukum Administrasi adalah wewenang, bukan kekuasaan. Wewenang atau kewenangan merupakan kekuasaan menurut hukum-hukum (rechtskraak/rechtmacht) yang diberikan kepada badan atau pejabat kenegaraan untuk melakukan tindakan pemerintahan dan/atau tindakan sesuai dengan aturan hukum yang menjadi dasar kewenangannya. Secara sederhana dapat didefinisikan bahwa wewenang atau kewenangan itu merupakan kekuasaan yang diberikan sekaligus pembatasan kekuasaan oleh hukum terhadap pejabat atau badan kenegaraan untuk dapat melakukan tindakan pemerintahan (bestuur handelingen) dan/atau tindakan lainnya, seperti tindakan hukum (rechthandelingen) dan tindakan nyata (feitelijk handelingen) sesuai dengan konformitas/prosedur diatur oleh hukum serta

${ }^{26}$ G.H.S Lumban Tobing, Peraturan Jabatan Notaris, Op.Cit., hlm.51-52.

Hasanuddin Kusuma Negara dan Moh. Saleh, Kewenangan Pembuatan Akta bagi Notaris yang berada di Daerah Provinsi Hasil Pemekaran 
ditujukan untuk menimbulkan akibat hukum tertentu bagi seseorang atau badan hukum.

Dalam perspektif hukum publik, negara merupakan organisasi jabatan. Menurut Logemann, dalam bentuk kenyataan sosialnya, negara merupakan organisasi yang berkenaan dengan berbagai fungsi. Fungsi merupakan lingkungan kerja yang terperinci dalam hubungannya secara keseluruhan. Fungsi-fungsi ini dinamakan jabatan. Negara merupakan organisasi jabatan. ${ }^{27}$

Dalam menjalankan suatu pemerintahan, dalam melakukan segala sesuatu harus dijalankan berdasarkan peraturan perundang-undangan yang berlaku. Indonesia menganut adanya asas legalitas, asas legalitas ini dikenal di dalam hukum pidana yang mengatakan "nullum delictum sine praevia lege poenali", yang artinya tidak ada suatu perbuatan hukum yang dapat dipidana tanpa ada peraturannya. ${ }^{28}$ Sedangkan didalam hukum administrasi negara juga digunakan asas legalitas yang mempunyai makna "dat het bestuur aan de wet is onderworpen", yang artinya bahwa pemerintah tunduk kepada undang-undang. ${ }^{29}$ Asas legalitas yang dimiliki oleh hukum administrasi negara mengatakan bahwa pemerintah dalam melakukan segala sesuatu harus tunduk kepada undang-undang dan pemerintah hanya dapat melakukan perbuatan hukum jika memiliki legalitas atau didasarkan kepada undang-undang yang merupakan perwujudan dari aspirasi masyarakat.

Soerjono Soekanto menguraikan perbedaan antara kekuasaan dan wewenang. Soerjono Soekanto mengatakan bahwa setiap kemampuan untuk mempengaruhi pihak lain dapat dinamakan kekuasaan, sedangkan wewenang adalah kekuasaan yang ada pada seseorang atau sekelompok orang, yang mempunyai dukungan atau mendapat pengakuan dari

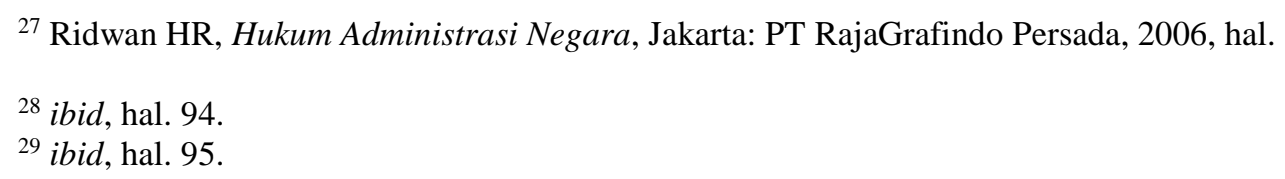

Hasanuddin Kusuma Negara dan Moh. Saleh, Kewenangan Pembuatan Akta bagi Notaris yang berada di Daerah Provinsi Hasil Pemekaran 
masyarakat. ${ }^{30}$ Kewenangan atau wewenang merupakan suatu istilah yang biasa digunakan dalam lapangan hukum publik. Namun sesungguhnya terdapat perbedaan diantara keduanya. Kewenangan adalah apa yang disebut "kekuasaan formal", kekuasaan yang berasal dari kekuasaan yang diberikan oleh Undang-undang atau legislatif dari kekuasaan eksekutif atau administratif. Karenanya, merupakan kekuasaan dari segolongan orang tertentu atau kekuasaan terhadap suatu bidang pemerintahan atau urusan pemerintahan tertentu yang bulat. Sedangkan wewenang hanya mengenai suatu bagian tertentu saja dari kewenangan. Wewenang (authority) adalah hak untuk memberi perintah, dan kekuasaan untuk meminta dipatuhi. ${ }^{31}$

Berdasarkan sumbernya, wewenang dibedakan menjadi dua, yaitu wewenang personal dan wewenang ofisial. Wewenang personal yaitu wewenang yang bersumber pada intelegensi, pengalaman, nilai atau norma, dan kesanggupan untuk memimpin. Sedangkan wewenang ofisial merupakan wewenang resmi yang diterima dari wewenang yang berada di atasnya. ${ }^{32}$ Berdasarkan prinsip negara hukum, adalah dengan adanya asas legalitas yang telah dianut di Indonesia, oleh sebab itu wewenang pemerintahan berasal dari peraturan perundang-undangan. Sehingga secara teori, kewenangan yang diperoleh atau didapat permerintah yang berasal dari peraturan perundang-undangan tersebut yang mengatur, dapat diperoleh melalui tiga cara, yaitu dengan atribusi, delegasi, dan mandat. ${ }^{33}$

H.D. Van Wijk/Willem Konijnenbelt menjelaskan tiga cara tersebut sebagai berikut: ${ }^{34}$

1) Atribusi yaitu pemberian wewenang pemerintahan dari pembuat undang-undang diberikan kepada organ pemerintahan.

${ }^{30}$ Soerjono Soekanto, Pokok-pokok Sosiologi Hukum, Jakarta: Raja Grafindo Persada, 2003, hal. 91-92.

31 “Teori Kewenangan", http://restuningmaharani.blogspot.com, diakses tanggal 1 Februari 2018.

${ }^{32}$ Ridwan HR, Hukum Administrasi Negara, hal. 73.

${ }^{33}$ Ridwan HR, op. cit, hal. 104.

${ }^{34}$ Ridwan HR, op. cit, hal. 105.

Hasanuddin Kusuma Negara dan Moh. Saleh, Kewenangan Pembuatan Akta bagi Notaris yang berada di Daerah Provinsi Hasil Pemekaran 
2) Delegasi yaitu pelimpahan wewenang pemerintahan oleh satu organ pemerintahan diberikan kepada organ pemerintahan lainnya.

3) Mandat yaitu terjadi ketika suatu organ pemerintahan memberikan atau mengizinkan kewenangannya dijalankan oleh organ lain atas namanya.

Selanjutnya, wewenang itu terdiri atas wewenang terikat dan wewenang bebas. Wewenang terikat artinya kewenangan itu sudah ditentukan secara limitatif oleh perundang-undangan yang menjadi sumber kewenangan itu. Dengan kata lain, perundang-undangan tidak memberikan pilihan lain kepada badan/pejabat tersebut untuk dapat melakukan tindakan lain selain dari apa yang telah ditentukan dalam perundang-undangan itu.

Kewenangan bebas (frije bevoedgheid/ freise ermessen) merupakan kewenangan yang oleh perundang-undangan itu diberikan pilihan kepada badan/pejabat dalam penggunaannya. Kewenangan itu bersifat pilihan artinya oleh perundang-undangan memang diberikan pilihan. Bisanya dalam perundang- ndangan menggunakan istilah 'dapat'. Misalnya, "Gubernur dapat mengangkat staf khusus", maka Gubernur diberikan kewenangan bebas untuk mengangkat atau tidak mengangkat staf khusus. Jadi kebabasan yang dimaksud bukanlah sebebas-bebasnya, melainkan telah ditentukan dalam perundang-undangan.

Dalam Hukum Administrasi, dikenal istilah kewenangan diskresi. Apa itu diskresi? Apakah diskresi itu sama dengan kewenangan bebas? Siapakah yang memiliki kewenangan diskresi?

Jika dilihat dari sumber wewenang, saya mengkualifikasikan kewenangan diskresi ini sebagai kewenangan jenis ketiga selain kewenangan atribusi dan delegasi (sedangkan mandat sebenarnya bukanlah wewenang). Namun, kewenangan diskresi ini dimiliki oleh badan/pejabat dalam ruang lingkup badan/pejabat pemerintahan ataupun tata usaha negara itu saja. Kewenangan diskresi ini ialah kewenangan yang oleh Hukum Administrasi diberikan serta merta kepada badan/pejabat pemerintahan sebagai bagian yang tidak terpisahkan dari jabatan yang diembannya.

Hasanuddin Kusuma Negara dan Moh. Saleh, Kewenangan Pembuatan Akta bagi Notaris yang berada di Daerah Provinsi Hasil Pemekaran 
Kewenangan diskresi diadakan oleh Hukum untuk dijadikan sarana atau instrumen hukum oleh badan/pejabat pemerintahan (het recht van bestuur) disaat badan/pejabat pemerintahan menghadapi situasi kekosongan atau kekaburan perundang-undangan yang menjadi dasar kewenangannya. Jadi tindakan yang dilakukannya tersebut masih dalam lingkup kewenangannya, namun perundang-undangan tidak mengatur atau pengaturannya tidak lengkap.

Dalam menggunakan kewengan diskresi, badan/pejabat pemerintahan hanya dapat menggunakannya ketika kebutuhan hukum menghendakinya. Maksudnya ialah jika tidak ada kebutuhan hukum yang dihadapi maka badan/pejabat pemerintahan tidak boleh menggunakannya.

Dalam contoh kasus di UUJN, kewenangan Majelis Kehormatan Notaris ditentukan terbatas dalam Pasal 66 ayat (1) huruf a dan huruf b UUJN. Semua aparat penegak hukum wajib tunduk pada ketentuan Pasal 66 tersebut. Akibat hukum dari tindakan aparat penegak hukum yang melaui proses Pasal 66 UUJN dalam pemeriksaan atau pemanggilan Notaris ialah tidak sah. Dengan kata lain, tindakan aparat penegak hukum yang dilakukan terhadap Notaris yang terkait dengan Pasal 66 ayat (1) huruf a dan huruf b wajib melalui persetujuan Majelis Kehormatan Notaris, jika tidak maka tindakan tersebut batal demi hukum.

Bagaimakah jika aparat penegak hukum mengajukan permohonan persetujuan kepada Majelis Kehormatan Notaris atas perbuatan Notaris di luar Pasal 66 ayat (1) UUJN? Jika aparat penegak hukum mengajukannya kepada Majelis Kehormatan Notaris, maka Majelis Kehormatan Notaris tidak boleh menolaknya dengan alasan tidak diatur dalam UUJN atau perundang-undangan lainnya. Nah, dalam konteks inilah Majelis Kehormatan Notaris menggunakan kewenangan diskresinya tersebut karena ada kebutuhan hukum untuk itu. Dengan kata lain, Majelis Kehormatan Notaris bersifat pasif jika diluar Pasal 66 ayat (1) huruf a dan huruf b karena tindakan aparat penegak hukum yang melakukan tindakan sebagaimana

Hasanuddin Kusuma Negara dan Moh. Saleh, Kewenangan Pembuatan Akta bagi Notaris yang berada di Daerah Provinsi Hasil Pemekaran 
diatur dalam Pasal 66 ayat (1) huruf a dan huruf $b$ tanpa melalui persetujuan Majelis Kehormatan Notaris maka tindakn tersebut batal demi hukum.

Oleh karena itu, dapatlah saya ringkas bahwa kewenangan diskresi itu haruslah mengandung unsur-unsur kumulatif sebagai berikut:

1) merupakan kewenangan badan/pejabat pemerintahan;

2) kewenangan tersebut masih dalam cakupan kewenangan atribusi atau delegasi yang dimilikinya;

3) adanya kebutuhan hukum sebagai akibat kekosongan atau kekaburan aturan hukum;

4) tidak boleh bertentangan dengan perundang-undangan dan asasasas umum pemerintahan yang baik.

\section{METODE PENELITIAN}

Penelitian ini bertipe penelitian hukum normatif, yakni "penelitian hukum yang dilakukan dengan cara meneliti bahan pustaka atau bahan hukum sekunder" sebagai pendukung bahan hukum primer berupa peraturan perundang-undangan dan putusan-putusan pengadilan. ${ }^{35}$

Pendekatan yang dipergunakan dalam penelitian hukum ini adalah pendekatan perundang-undangan (statute approach) dan pendekatan konseptual (conceptual approach).

Pendekatan perundang-undangan (statute approach) yaitu, "Pendekatan yang dilakukan dengan menelaah semua undang-undang dan regulasi yang bersangkut paut dengan isu hukum yang sedang ditangani" 36 . Dalam kaitan dengan pendekatan perundang-undangan dan pendekatan konseptual, maka peneliti akan meneliti semua perundang-undangan di bidang kenotariatan dan pemekaran daerah.

Sedangkan pendekatan konseptual (conceptual approach) adalah, "Pendekatan yang beranjak dari perundang-undangan dan doktrin-doktrin

${ }^{35}$ Soerjono Soekanto \& Sri Mamudji, Penelitian Hukum Normatif, Suatu tinjauan Singkat, Rajawali Pers. Jakarta, 2010, h. 15. 2007, h. 93.

36 Peter Mahmud Marzuki, Penelitian Hukum, Kencana Prenada Media Group, Jakarta,

Hasanuddin Kusuma Negara dan Moh. Saleh, Kewenangan Pembuatan Akta bagi Notaris yang berada di Daerah Provinsi Hasil Pemekaran 
yang berkembang di dalam ilmu hukum. Pemahaman akan pandanganpandangan dan doktrin-doktrin tersebut merupakan sandaran bagi peneliti dalam membangun argumentasi hukum dalam memecahkan isu yang dihadapi". ${ }^{37}$ Pendekatan konseptual dimaksudkan untuk menelusuri doktrindoktrin mengenai hukum di bidang kenotariatan dan pemekaran daerah.

\section{E. PEMBAHASAN}

1. Batasan Kewenangan Pembuatan Akta bagi Notaris yang berada di Daerah Provinsi Hasil Pemekaran.

Notaris dalam menjalankan jabatannya sebagai Pejabat Umum (Openbare Ambtenare), di dalam kewenangannya mempunyai batasanbatasan kewenangan. Batasan-batasan tersebut yaitu mengenai :

1) isi/materi (materiae)

2) wilayah/ruang (locus)

3) waktu (tempus)

Ketiga batasan tersebut diuraikan lebih lanjut dalam Undang-undang Jabatan Notaris dan peraturan-peraturan maupun perundang-undangan lain yang berkaitan dengan Jabatan Notaris.

\section{A. Batasan Kewenangan Notaris dalam Lingkup Isi / Materi.}

Seorang Notaris mempunyai kewenangan yang dibatasi oleh materi, dalam hal ini dimaksudkan kewenangan Jabatan Notaris terbatas terhadap tindakan maupun produk hukum yang dikeluarkan oleh Notaris harus tunduk dan patuh terhadap perintah undang-undang dan atau peraturan-peraturan yang ada.

Kewenangan Notaris dalam lingkup isi / materi diatur di dalam UUJN yaitu pasal 1 dan pasal 15. Bunyi pasal 1 UUJN yaitu "Notaris adalah pejabat umum yang berwenang untuk membuat akta otentik dan kewenangan lainnya sebagaimana dimaksud dalam undang-undang

${ }^{37}$ Ibid.

Hasanuddin Kusuma Negara dan Moh. Saleh, Kewenangan Pembuatan Akta bagi Notaris yang berada di Daerah Provinsi Hasil Pemekaran 
ini." 38 Selanjutnya Pasal 15 UUJN menjelaskan bahwa kewenangan Notaris : ${ }^{39}$

\section{PASAL 15}

(1) Notaris berwenang membuat Akta autentik mengenai semua perbuatan, perjanjian, dan penetapan yang diharuskan oleh peraturan perundang-undangan dan/atau yang dikehendaki oleh yang berkepentingan untuk dinyatakan dalam Akta autentik, menjamin kepastian tanggal pembuatan Akta, menyimpan Akta, memberikan grosse, salinan dan kutipan Akta, semuanya itu sepanjang pembuatan Akta itu tidak juga ditugaskan atau dikecualikan kepada pejabat lain atau orang lain yang ditetapkan oleh undang-undang.

(2) Selain kewenangan sebagaimana dimaksud pada ayat (1), Notaris berwenang pula:

a. mengesahkan tanda tangan dan menetapkan kepastian tanggal surat di bawah tangan dengan mendaftar dalam buku khusus;

b. membukukan surat di bawah tangan dengan mendaftar dalam buku khusus;

c. membuat kopi dari asli surat di bawah tangan berupa salinan yang memuat uraian sebagaimana ditulis dan digambarkan dalam surat yang bersangkutan;

d. melakukan pengesahan kecocokan fotokopi dengan surat aslinya;

e. memberikan penyuluhan hukum sehubungan dengan pembuatan Akta;

f. membuat Akta yang berkaitan dengan pertanahan; atau

g. membuat Akta risalah lelang.

(3) Selain kewenangan sebagaimana dimaksud pada ayat (1) dan ayat (2), Notaris mempunyai kewenangan lain yang diatur dalam peraturan perundang-undangan.

Dalam hal Kewenangan Notaris yang tersebut dalam Pasal 15 ayat (2) huruf f dan g, “...Akta yang berkaitan dengan pertanahan; dan membuat Akta risalah lelang sejak diberlakukan UUJN belum bisa dilaksanakan, karena kewenangan membuat akta dengan pertanahan

\footnotetext{
${ }^{38}$ Pasal 1 UUJN

${ }^{39}$ Pasal 15 UUJN
}

Hasanuddin Kusuma Negara dan Moh. Saleh, Kewenangan Pembuatan Akta bagi Notaris yang berada di Daerah Provinsi Hasil Pemekaran 
masih menjadi Kewenangan Pejabat Pembuat Akta Tanah (PPAT)..."40 dan “... Akta Risalah Lelang masih menjadi kewenangan Pejabat Lelang..."41

Kewenangan lain Notaris yang diatur dalam dalam peraturan perundang-undangan antara lain :

1. Surat Kuasa Membebankan Hak Tanggungan.

Undang-undang Nomor 4 Tahun 1996 tentang Hak Tanngungan Atas Tanah beserta Benda-Benda yang berkaitan dengan Tanah (UUHT), Pasal 15 ayat (1) UUHT, yaitu : Surat Kuasa Membebankan Hak Tanggungan wajib dibuat dengan Akta Notaris atau Akta PPAT.

2. Akta Penyelesaian Sengketa Arbitrase.

Undang-undang Nomor 30 Tahun 1999 tentang Arbitrase dan Alternatif Penyelesaian Sengketa. Di dalam Pasal 9 disebutkan bahwa penyelesaian sengketa melalui Arbitrase setelah sengketa terjadi harus dengan Akta Notaris.

3. Akta Fidusia.

Undang-undang Nomor 42 tahun 1999 tentang Jaminan Fidusia. DI dalam Pasal 5 ayat (1) ditegaskan bahwa Akta Fidusia harus dibuat dengan Akta Notaris.

4. Akta Pendirian Yayasan.

Undang-undang Republik Indonesia Nomor 16 Tahun 2001 Tentang Yayasan sebagaimana dimaksud dalam ayat (1) dilakukan dengan Akta Notaris dan dibuat dalam bahasa Indonesia.

5. Akta Pendirian Perseroan Terbatas (PT).

Undang-undang Republik Indonesia Nomor 40 Tahun 2007 Tentang Perseroan Terbatas. Di dalam pasal 7 ayat (1) ditegaskan bahwa

${ }^{40}$ Habib Adjie, Penafsiran Tematik Hukum Notaris Indonesia, Refika Aditama, Bandung, 2015, hal 9.

${ }^{41}$ Ibid. Hal. 10.

Hasanuddin Kusuma Negara dan Moh. Saleh, Kewenangan Pembuatan Akta bagi Notaris yang berada di Daerah Provinsi Hasil Pemekaran 
Perseroan didirikan oleh 2 (dua) orang atau lebih dengan Akta Notaris yang dibuat dalam bahasa Indonesia.

6. Akta Pendirian Partai Politik.

Undang-undang Republik Indonesia Nomor 2 Tahun 2011 Tentang Perubahan Atas Undang-undang Nomor 2 Tahun 2008 Tentang Partai Politik. Dalam Pasal 2 ayat (1a) ditegaskan bahwa : Pendirian Partai Politik dengan Akta Notaris.

\section{B. Batasan Kewenangan Notaris dalam Lingkup Wilayah / Ruang.}

Dalam menjalankan kewenangannya, seorang Pejabat Notaris dibatasi oleh wilayah atau ruang yaitu tempat kedudukan dan wilayah jabatan Notaris. Sesuai UUJN diatur dalam Pasal 18 dan Pasal 19. Sebagai berikut :

\section{PASAL 18}

(1) Notaris mempunyai tempat kedudukan di daerah kabupaten atau kota.

(2) Notaris mempunyai wilayah jabatan meliputi seluruh wilayah provinsi dari tempat kedudukannya.

\section{PASAL 19}

(1) Notaris wajib mempunyai hanya satu kantor, yaitu di tempat kedudukannya.

(2) Notaris tidak berwenang secara teratur menjalankan jabatan di luar tempat kedudukannya.

Dari bunyi Pasal 18 UUJN tersebut dapat disimpulkan bahwa Notaris tempat kedudukannya berada di daerah kabupaten atau kota; dan wilayah jabatannya seluruh wilayah provinsi dari tempat kedudukannya. Selanjutnya Pasal 19 UUJN menjelaskan bahwa Notaris hanya berhak mempunyai satu kantor saja di tempat kedudukan Notaris tersebut. Dengan adanya syarat tambahan, Notaris dilarang membuat akta diluar wilayah Jabatan secara teratur atau berturut-turut.

Hasanuddin Kusuma Negara dan Moh. Saleh, Kewenangan Pembuatan Akta bagi Notaris yang berada di Daerah Provinsi Hasil Pemekaran 


\section{Batasan Kewenangan Notaris dalam Lingkup Waktu.}

Notaris dalam menjalankan jabatannya, dibatasi oleh jangka waktu. Yaitu kewenangan Notaris sudah berlaku sejak diterbitkannya Surat Keputusan Pengangkatan Notaris yang bersangkut. Daripada itu Notaris jika dalam masa cuti dilarang menjalankan Jabatannya. Selanjutnya masa pensiun Notaris jika sudah berumur 65 (enam puluh lima) tahun sesuai dengan bunyi UUJN pasal 8 ayat (1) huruf b "Notaris berhenti atau diberhentikan dari Jabatannya dengan hormat karena telah berumur 65 (enam puluh lima) tahun".

Dari uraian di atas mengenai batasan kewenangan Notaris meliputi isi/materi, ruang/wilayah, dan waktu. Jika dikaitkan dengan adanya pemekaran daerah, maka ditarik kesimpulan pemekaran daerah berkaitan dengan batasan kewenangan Notaris dalam lingkup ruang/wilayah.

Notaris yang berada di daerah pemekaran, dapat diartikan kantor notaris yang bersangkutan berada di daerah yang mengalami pemekaran dan mengakibatkan perubahan nama provinsi, meskipun kantor Notaris yang bersangkutan tidak berpindah. Mengakibatkan Notaris wilayah jabatannya mengikuti wilayah jabatan Notaris yang baru tersebut, yaitu Provinsi hasil pemekaran. Sedangkan daerah Induk dari pemekaran provinsi sudah tidak menjadi wilayah Jabatan Notaris yang bersangkutan. Hal ini secara sederhana berpedoman pada tempat kedudukan Notaris sesuai Pasal 18 ayat 2 UUJN yang berbunyi "Notaris mempunyai wilayah jabatan meliputi seluruh wilayah provinsi dari tempat kedudukannya".

Hal ini dapat disimpulkan bahwa wilayah Jabatan Notaris melekat dengan tempat kedudukan. Sehingga tidak perlu ditafsirkan lain lagi, walaupun terjadi perubahan Povinsi atas adanya pemekaran daerah, wilayah jabatan Notaris mengikuti daripada tempat kedudukan atau kantor Notaris tersebut berada.

Hasanuddin Kusuma Negara dan Moh. Saleh, Kewenangan Pembuatan Akta bagi Notaris yang berada di Daerah Provinsi Hasil Pemekaran 


\section{Akibat Hukum Pembuatan Akta bagi Notaris yang berada di Daerah Provinsi Hasil Pemekaran.}

Seorang Notaris dalam menjalankannya jabatannya mempunyai batasan-batasan kewenangan yang sudah diuraikan sebelumnya, yaitu batasan kewenangan dalam lingkup isi/materi, ruang/wilayah, dan waktu.

Akibat hukum yang timbul dengan adanya cacat atau tidak terpenuhinya syarat-syarat kewenangan mengenai isi/materi, ruang/wilayah, dan waktu. Dapat mengakibatkan tindakan tanpa kewenangan (Onbevoegheid). Tindakan tanpa wewenang bisa berupa :

1) onbevoegdheid ratione materiae,

2) onbevoegdheid ratione loci, dan

3) onbevoegdheid ratione temporis.

Dari ketiga batasan tersebut yang berkaitan dengan adanya pemekaran daerah adalah batasan kewenangan dalam lingkup ruang/wilayah. Jika Notaris yang bersangkutan membuat akta di luar wilayah Jabatan dalam hal ini Notaris tetap membuat akta di daerah Induk pemekaran, maka Notaris tersebut telah bertindak tanpa wewenang dikarenakan tempat (onbevoegdheid ratione loci).

Akta yang dibuat Notaris tanpa ada kewenangannya maka dapat disimpulkan bahwa akta yang bersangkutan batal demi hukum, dan semua perbuatan atau tindakan hukum yang tersebut dalam akta harus dianggap tidak pernah terjadi. Dan akta seperti ini tidak bisa dieksekusi. Untuk Notaris yang membuat aktanya dapat dituntut penggantian biaya, ganti rugi, dan bunga dengan alasan ketidaktahuan Notaris akan ketidakwenangannya tidak untuk membuat akta yang bukan menjadi kewenangannya. ${ }^{42}$

\section{F. Penutup}

\section{Simpulan}

\section{${ }^{42}$ Ibid. Hal. 14}

Hasanuddin Kusuma Negara dan Moh. Saleh, Kewenangan Pembuatan Akta bagi Notaris yang berada di Daerah Provinsi Hasil Pemekaran 
Hasil dari pembahasan diatas dapat disimpulkan :

1) Batasan kewenangan pembuatan akta bagi Notaris yang berada di daerah provinsi hasil pemekaran, yaitu batasan kewenangan Notaris dalam lingkup ruang/wilayah (locus). Batasan kewenangan tersebut dijelaskan pada Pasal 18 dan Pasal 19 UUJN. Sehingga apabila terjadi pemekaran provinsi yang menyebabkan perubahan nama provinsi, Notaris tetap berhak atau berwenang selama Notaris bersangkutan menjalankan jabatannya tetap pada tempat kedudukan atau kantor Notaris tersebut berada. Hal ini juga mengakibatkan lebih kecilnya wilayah jabatan Notaris karena adanya pemekaran daerah, karena terjadinya perpecahan atau terbaginya wilayah jabatan sebelumnya menjadi daerah induk atau provinsi lama dengan daerah pemekaran atau provinsi baru.

2) Akibat hukum pembuatan akta bagi Notaris yang berada di daerah provinsi hasil pemekaran, yaitu jika Notaris tempat kedudukannya berada di daerah pemekaran maka akta Notaris tersebut sah, tetapi jika Notaris tersebut tempat kedudukannya berada di daerah Induk pemekaran, mengakibatkan Notaris menjalankan kewenangan di luar wilayah jabatan, dengan adanya pelanggaran kewenangan atau cacat wewenang dalam lingkup tempat (locus) tersebut, yaitu tindakan tersebut tidak sah dikarenakan wewenang cacat tempat (onbevoegdheid ratione loci). Akta yang bersangkutan batal demi hukum, dan semua perbuatan atau tindakan hukum yang tersebut dalam akta harus dianggap tidak pernah terjadi. Dan akta seperti ini tidak bisa dieksekusi. Selanjutnya ntuk Notaris yang bersangkutan dapat dituntut penggantian biaya, ganti rugi, dan bunga dengan alasan ketidaktahuan Notaris akan ketidakwenangannya.

\section{Saran}

Saran dari penulis yaitu pembuat aturan atau undang-undang seharusnya menjelaskan lebih detail terhadap tindakan Notaris dengan

Hasanuddin Kusuma Negara dan Moh. Saleh, Kewenangan Pembuatan Akta bagi Notaris yang berada di Daerah Provinsi Hasil Pemekaran 
adanya pemekaran daerah. Sehingga tidak menimbulkan kekosongan hukum maupun menimbulkan multi tafsir atau beda pendapat di kalangan Notaris terhadap adanya pemekaran daerah. Walau tidak mengesampingkan Notaris sebagai Jabatan sekaligus profesi dituntut bekerja setiap hari, sehingga tidak mungkin atau tidak serta merta Notaris dilarang untuk membuat akta dikarenakan adanya Pemekaran daerah selama Notaris tetap menjalankan tugasnya di tempat kedudukan atau Kantor Notaris sesuai SK yang sebelumnya didapat.

Menyadari bahwa penulis masih jauh dari kata sempurna, ke depannya penulis akan lebih fokus dan detail dalam menjelaskan tentang permasalahan di atas dengan sumber-sumber yang lebih banyak yang tentunya dapat dipertanggung jawabkan.

\section{Daftar Pustaka}

\section{BUKU}

Anke Dwi Saputra, Jati Diri Notaris Indonesia Dulu, Sekarang, dan di Masa Yang Akan Datang, Jakarta: PT. Gramedia, 2008.

G.H.S. Lumban Tobing, Peraturan Jabatan Notaris, Jakarta: Erlangga.

Habib Adjie, Penafsiran Tematik Hukum Notaris Indonesia, Bandung: Refika Aditama, 2015.

Herlien Budiono, Kumpulan Tulisan Hukum Perdata di Bidang Kenotariatan, Bandung : Citra Aditya Bakti, 2007.

Hasanuddin Kusuma Negara dan Moh. Saleh, Kewenangan Pembuatan Akta bagi Notaris yang berada di Daerah Provinsi Hasil Pemekaran 
Irwan Soerodjo, Kepastian Hukum Hak ATas Tanah di Indonesia, Surabaya : Arkola, 2003

Peter Mahmud Marzuki, Penelitian Hukum, Jakarta : Kencana Prenada Media Group, 2007.

R. Soegondo, Hukum Pembuktian, Jakarta : PT. Pradnya Paramita, 1991.

Ridwan HR, Hukum Administrasi Negara, Jakarta: PT RajaGrafindo Persada, 2006.

Sjaifurrachman dan Habib Adjie, Aspek Pertanggungjawaban Notaris Dalam Pembuatan Akta, Bandung : Mandar Maju, 2011.

Soerjono Soekanto \& Sri Mamudji, Penelitian Hukum Normatif, Suatu Tinjauan Singkat, Jakarta : Rajawali Pers, 2010.

Soerjono Soekanto, Pokok-pokok Sosiologi Hukum, Jakarta: Raja Grafindo Persada, 2003.

Than Thong Kie, Studi Notariat, Serba Serbi Praktek Notaris, Jakarta: PT Ichtiar Baru Van Hoeve, 2007.

\section{INTERNET}

“Asas-asas Hukum", http://serbaserbiilmuhukum.blogspot.com diakses pada tanggal 1 Februari 2018.

"Data Wilayah Administrasi Seluruh Indonesia", www.kemendagri.go.id diakses pada tanggal 1 Februari 2018.

"Teori Kewenangan", http://restuningmaharani.blogspot.com, diakses tanggal 1 Februari 2018.

Hasanuddin Kusuma Negara dan Moh. Saleh, Kewenangan Pembuatan Akta bagi Notaris yang berada di Daerah Provinsi Hasil Pemekaran 


\section{PERATURAN PERUNDANG-UNDANGAN}

Kitab Undang-Undang Hukum Perdata.

Undang - Undang Republik Indonesia Nomor 2 Tahun 2014 tentang Jabatan Notaris.

Peraturan Menteri Hukum dan Hak Asasi Manusia Republik Indonesia Nomor 25 Tahun 2014 tentang syarat dan tata cara pengangkatan, perpindahan, pemberhentian, dan perpanjangan masa Jabatan Notaris.

Reglement Op Het Notaris ambt in Indonesia (Stb. 1860:3) sebagaimana telah diubah terakhir dalam Lembaran Negara Th. 1945 No. 101. 